\title{
PROFIL GELATINISASI DAN KOMPONEN ANTIOKSIDAN TEPUNG KETAN HITAM TERMODIFIKASI DENGAN ANNEALING
}

\author{
[Gelatinization Profile and Antioxidant Components of Annealing-Modified \\ Black Glutinous Rice Flour]
}

\author{
Riezka Zuhriatika Rasyda ${ }^{1) \star}$, Tjahja Muhandri ${ }^{2,3)}$, dan Slamet Budijanto ${ }^{2,3)}$ \\ 1) Program Studi Magister IImu Pangan, Sekolah Pascasarjana, IPB University, Bogor \\ 2) Departemen Ilmu dan Teknologi Pangan, Fakultas Teknologi Pertanian, IPB University, Bogor \\ 3) Southeast Asian Food and Agricultural Science and Technology (SEAFAST) Center, IPB University, Bogor
}

Diterima 25 Juni 2020 / Disetujui 15 Oktober 2020

\begin{abstract}
This research aims to study and characterize the effect of the annealing conditions (temperature and heating duration) on the gelatinization profile and antioxidant components of annealing-modified black glutinous rice flour (ABGRF). This experiment used a $2 \times 3$ factorial design consisted of temperature factor $\left(54\right.$ and $\left.58^{\circ} \mathrm{C}\right)$ and heating duration factor $(4,5$, and 6 hours) with 2 replications. Research results showed that both factors and their interactions significantly affected all parameters of the gelatinization profile and antioxidant component of ABGRF (except through viscosity). Compared to its native, ABGRF showed an increase in peak viscosity, through viscosity (except treatment $54^{\circ} \mathrm{C}: 5$ hours), peak time and pasting temperature, indicated ABGRF resistance improvement to the heating process. Generally, the temperature treatment increment increased breakdown, setback, and final viscosity, but the heating duration increment decreased those values. The variation of ABGRF gelatinization profiles increased the diversification potential of BGRF-based food products. Annealing caused an overall decrease in ABGRF antioxidant ability. ABGRF produced by $54^{\circ} \mathrm{C}: 4$ hours treatment had the highest amount of antioxidant components (total anthocyanins contents $103.78 \pm 2.24 \mathrm{mg} C 3 \mathrm{GE} / 100 \mathrm{~g}$, total phenolic compounds $241.65 \pm 1.98 \mathrm{mg}$ GAE/100 g, DPPH 267.14 $3.23 \mathrm{mg} \mathrm{AAE} / 100 \mathrm{~g}$, FRAP $473.94 \pm 1.43 \mathrm{mg} \mathrm{AAE} / 100 \mathrm{~g}$ ), thus using it as ingredients in functional food is more recommended, especially as composite flour for bread and cake.
\end{abstract}

Keywords: annealing, antioxidant, black glutinous rice flour, black glutinous rice, gelatinization

\begin{abstract}
ABSTRAK
Penelitian ini bertujuan untuk mengkaji dan mengkarakterisasi pengaruh kondisi annealing (suhu dan lama pemanasan) terhadap profil gelatinisasi dan komponen antioksidan tepung ketan hitam termodifikasi annealing (TKHA). Penelitian ini menggunakan Rancangan Faktorial $2 \times 3$, terdiri dari faktor suhu (54 dan $58^{\circ} \mathrm{C}$ ) dan faktor lama pemanasan $(4,5$, dan 6 jam) dengan 2 ulangan. Hasil penelitian menunjukkan bahwa kedua faktor dan interaksi keduanya memberikan pengaruh yang signifikan terhadap semua parameter pada profil gelatinisasi maupun komponen antioksidan TKHA (kecuali viskositas panas). Dibandingkan dengan TKH, TKHA menunjukkan adanya peningkatan pada viskositas puncak, viskositas panas (kecuali perlakuan $54^{\circ} \mathrm{C}: 5 \mathrm{jam}$ ), waktu puncak dan suhu awal gelatinisasi, mengindikasikan peningkatan daya tahan TKHA terhadap proses pemanasan. Secara umum, peningkatan suhu pemanasan meningkatkan viskositas jatuh, viskositas akhir dan viskositas balik, sementara peningkatan lama pemanasan menurunkan viskositas tersebut. Profil gelatinisasi TKHA yang bervariasi meningkatkan potensi diversifikasi produk pangan berbasis TKH. Annealing menyebabkan penurunan kemampuan antioksidan TKHA secara keseluruhan. Perlakuan $54^{\circ} \mathrm{C}: 4$ jam menghasilkan TKHA dengan kadar komponen antioksidan tertinggi dari seluruh perlakuan (total antosianin 103,78 $\pm 2,24 \mathrm{mg} \mathrm{C} 3 \mathrm{GE} / 100 \mathrm{~g}$, total senyawa fenolik $241,65 \pm 1,98 \mathrm{mg}$ GAE/100 g, DPPH $267,14 \pm 3,23 \mathrm{mg} \mathrm{AAE} / 100 \mathrm{~g}$, FRAP $473,94 \pm 1,43 \mathrm{mg} \mathrm{AAE} / 100 \mathrm{~g}$ ), sehingga lebih direkomendasikan penggunaannya dalam pengolahan pangan fungsional, terutama sebagai tepung komposit dalam pembuatan roti dan kue.
\end{abstract}

Kata kunci: annealing, antioksidan, beras ketan hitam, gelatinisasi, tepung ketan hitam

*Penulis Korespondensi:

E-mail: riezka_rasyda44@apps.ipb.ac.id 


\section{PENDAHULUAN}

Beras ketan (Oryza sativa glutinosa L.) merupakan salah satu jenis beras yang umum digunakan dalam industri pangan. Beras ketan hitam (BKH) memiliki kelebihan dari jenis beras ketan lainnya berupa kandungan komponen bioaktif yang tinggi, terutama total antosianinnya (Goufo dan Trindade, 2014). Antosianin memiliki berbagai manfaat kesehatan, salah satunya yaitu sebagai antioksidan yang bermanfaat mencegah terjadinya berbagai jenis penyakit degeneratif serta penuaan dini (Phetpornpaisan et al., 2014). Total antosianin BKH dapat mencapai $179,30 \mathrm{mg} / 100 \mathrm{~g}$ (Nindita et al., 2018), jauh lebih tinggi dari beras ketan putih $(0,32$ $\mathrm{mg} / 100 \mathrm{~g}$ ) (Ponnappan et al., 2017) maupun beras ketan merah (17 mg/100 g) (Abdullah, 2017), sehingga menjadi pilihan terbaik dalam pengolahan pangan fungsional berbasis ketan.

Tepung ketan hitam (TKH) merupakan produk turunan pertama dari BKH. Produk olahan dari $\mathrm{TKH}$ umumnya bertekstur kenyal dan lengket karena kandungan amilosanya yang rendah $\leq 2 \%$ (waxy starch) (Sompong et al., 2011). Kandungan amilosa yang rendah mengakibatkan TKH menghasilkan karakteristik gel yang tidak tahan panas dan mudah hancur jika diaduk (Šárka dan Dvořáček, 2017), sehingga mempersempit peluang diversifikasi karena sulit diaplikasikan pada produk pangan yang pengolahannya melibatkan proses pengadukan dan suhu tinggi. Karakteristik tersebut berkaitan erat dengan profil gelatinisasi TKH sebagai waxy starch, yaitu viskositas puncak dan viskositas jatuh yang tinggi serta viskositas akhir dan viskositas balik yang rendah (Šárka dan Dvořáček, 2017). Semakin besar viskositas jatuh maka semakin rendah daya tahan TKH terhadap perubahan akibat panas, sedangkan semakin besar viskositas balik maka semakin besar juga kecenderungan TKH untuk mengalami retrogradasi (Zavareze dan Dias, 2011).

Profil gelatinisasi TKH dapat diubah menjadi lebih tahan panas dan pengadukan melalui proses modifikasi dengan metode pemanasan-pendinginan (annealing). Annealing adalah suatu proses hidrotermal dengan cara memanaskan granula pati dengan kadar air berlebih pada suhu di bawah suhu gelatinisasi dan di atas suhu transisi gelas (BeMiller, 2018). $\mathrm{Li}$ et al. (2018) menyatakan bahwa tepung ketan putih termodifikasi annealing mengalami perubahan profil gelatinisasi berupa suhu gelatinisasi yang lebih tinggi serta viskositas jatuh dan viskositas balik yang lebih rendah yang dipengaruhi oleh faktor suhu dan lama pemanasan saat proses annealing.

Perlakuan suhu dan lama pemanasan pada proses annealing dapat memengaruhi kemampuan antioksidan TKH. Suhartatik et al. (2013) menyatakan bahwa proses pemanasan $\mathrm{BKH}$ selama 60 menit pada suhu $\geq 60^{\circ} \mathrm{C}$ dapat menyebabkan hilang- nya kemampuan antioksidan $\mathrm{BKH}$, seiring dengan semakin lamanya waktu pemanasan maka semakin rendah pula kadar total antosianin yang dikandungnya. Nindita et al. (2018) juga melaporkan bahwa seiring dengan semakin meningkatnya suhu pemanasan TKH dalam proses ekstrusi maka semakin berkurang pula kadar total senyawa fenolik dan total antosianin yang dikandungnya, sehingga ikut menurunkan kapasitas antioksidan TKH. Berbagai penelitian terdahulu menunjukkan bahwa annealing dapat mengubah karakteristik alami pati, namun belum ada penelitian yang melaporkan tentang modifikasi annealing terhadap TKH serta pengaruhnya terhadap profil gelatinisasi dan komponen antioksidan, sehingga dilakukan penelitian ini dengan tujuan untuk mengkaji dan mengkarakterisasi pengaruh kondisi annealing (suhu dan lama pemanasan) terhadap profil gelatinisasi dan komponen antioksidan (total senyawa fenolik (TSF), total antosianin (TA) dan kapasitas antioksidan) TKH termodifikasi annealing (TKHA).

\section{BAHAN DAN METODE}

\section{Bahan}

Bahan yang digunakan dalam penelitian ini adalah beras ketan hitam $(\mathrm{BKH})$ unggulan lokal varietas Setail yang diperoleh dari petani di daerah Dompu, Nusa Tenggara Barat.

\section{Proses pembuatan TKH}

Proses pembuatan TKH melibatkan proses penyosohan BKH terlebih dahulu menggunakan abbrasive polisher (Rice Grain Mill, Jepang) selama 2 menit hingga didapatkan fraksi $\mathrm{BKH}$ sosoh dan fraksi bekatul. Fraksi BKH sosoh ditepungkan menggunakan pin disc mill (AGC21, Indonesia) dan kemudian dicampur dengan fraksi bekatul. Tepung hasil pencampuran diayak dengan vibrating screen 80 mesh hingga dihasilkan TKH yang kemudian dikemas menggunakan plastik PP dan disimpan pada suhu $-18^{\circ} \mathrm{C}$ sampai saatnya digunakan.

\section{Modifikasi annealing TKH}

Proses annealing TKH dilakukan dengan memodifikasi suhu dan lama pemanasan yang digunakan pada metode Li et al. (2018). Proses annealing diawali dengan pencampuran sampel TKH dan air (1:2) yang kemudian diinkubasi di dalam shaking waterbath (SWBR17, USA) dengan suhu dan lama pemanasan sesuai perlakuan (suhu $54^{\circ} \mathrm{C}: 4$ jam, suhu $54^{\circ} \mathrm{C}: 5$ jam, suhu $54^{\circ} \mathrm{C}: 6$ jam, suhu $58^{\circ} \mathrm{C}: 4$ jam suhu $58^{\circ} \mathrm{C}: 5$ jam, suhu $58^{\circ} \mathrm{C}: 6$ jam). Titik suhu tersebut telah ditentukan sebelumnya berdasarkan hasil analisis suhu transisi gelas dan suhu awal gelatinisasi pada analisis pendahuluan menggunakan disc scanning calorimetri (STA 449 F1 Jupiter, 
Jerman). Sampel TKHA dikeringkan menggunakan pengering kabinet (Engineering \& Equipment $\mathrm{GmbH}$ 6072 , Jerman) pada suhu $\pm 40^{\circ} \mathrm{C}$ selama 45 menit hingga kadar airnya mencapai $\pm 10 \%$, kemudian dikemas menggunakan plastik PP dan disimpan pada suhu $-18^{\circ} \mathrm{C}$ sampai saatnya digunakan.

\section{Karakterisasi TKHA}

Karakterisasi TKHA dilakukan terhadap profil gelatinisasi dan komponen antioksidannya. Analisis profil gelatinisasi dilakukan berdasarkan metode Nindita et al. (2018) menggunakan rapid visco analyzer (RVA-4500, Swedia). Analisis komponen antioksidan dilakukan terhadap filtrat sampel yang didapat dari hasil ekstraksi TKHA berdasarkan metode Zulfafamy et al. (2018). Komponen antioksidan yang dianalisis yaitu total senyawa fenolik (Chen et al., 2015), total antosianin (Sutharut dan Sudarat, 2012) dan kapasitas antioksidan berdasarkan metode 2,2-Diphenyl-1-Picrylhydrazyl (DPPH) (Bobo-García et al., 2015) dan ferric reducing antioxidant power (FRAP) (Zahin et al., 2013).

\section{Rancangan percobaan dan analisis data}

Rancangan percobaan yang digunakan adalah Rancangan Faktorial dengan 2 faktor. Faktor 1 adalah suhu pemanasan $\left(54\right.$ dan $\left.58^{\circ} \mathrm{C}\right)$ dan faktor 2 adalah lama pemanasan $(4,5$, dan 6 jam), menghasilkan kombinasi desain perlakuan $2 \times 3$ (suhu $54^{\circ} \mathrm{C}: 4$ jam, suhu $54^{\circ} \mathrm{C}: 5$ jam, suhu $54^{\circ} \mathrm{C}: 6$ jam, suhu $58^{\circ} \mathrm{C}: 4$ jam, suhu $58^{\circ} \mathrm{C}: 5$ jam, suhu $58^{\circ} \mathrm{C}: 6$ jam). Data yang dilaporkan merupakan nilai rerata \pm standar deviasi dari 2 kali ulangan untuk tiap perlakuan dan kontrol (TKH alami), sehingga didapatkan data dari 14 unit percobaan. Data hasil percobaan diolah dengan perangkat lunak SPSS 23.0 (USA) dan dianalisis menggunakan two-way analysis yang ditampilkan dalam bentuk ANOVA (taraf nyata $5 \%$ ) untuk identifikasi perbedaan antartaraf perlakuan. Hasil berbeda pada taraf perlakuan diuji lanjut dengan Duncan's Multiple Range Test
(DMRT), sedangkan korelasi hasil penelitian antarparameter diukur menggunakan koefisien korelasi Pearson's $(r)$.

\section{HASIL DAN PEMBAHASAN}

\section{Profil gelatinisasi}

Profil gelatinisasi dapat menunjukkan karakteristik fungsional TKHA, sehingga dapat digunakan sebagai salah satu indikator terkait potensi aplikasinya pada produk pangan. Selisih antara viskositas puncak (peak viscosity, PV) dan viskositas panas (through viscosity, TV) pada profil gelatinisasi menghasilkan viskositas jatuh (breakdown viscosity, BD). Peningkatan PV mengindikasikan peningkatan kemampuan penyerapan air dan daya kembang TKHA, sedangkan peningkatan BD mengindikasikan peningkatan daya tahan TKHA terhadap perubahan akibat panas dan pengadukan (Kang et al., 2010). Viskositas akhir (final viscosity, FV) dan viskositas balik (setback viscosity, SB) mengindikasikan tekstur akhir produk olahan TKHA. Peningkatan FV dan SB mengindikasikan kecenderungan TKHA untuk mengalami peningkatan viskositas setelah pendinginan, sehingga tekstur akhir produk pun semakin padat dan kompak (Zavareze dan Dias, 2011).

Hasil analisis keragaman pada Tabel 1 menunjukkan bahwa proses annealing memberikan pengaruh yang signifikan $(P<0,05)$ terhadap profil gelatinisasi $\mathrm{TKH}$, terlihat dari adanya beda nyata antara profil gelatinisasi TKH (kontrol) dan TKHA serta antartiap perlakuan TKHA. Faktor suhu pemanasan memberikan pengaruh yang signifikan $(P<0,05)$ terhadap semua parameter pada profil gelatinisasi kecuali pada nilai TV $(P>0,05)$. Peningkatan suhu pemanasan dari 54 menjadi $58^{\circ} \mathrm{C}$ dengan lama pemanasan yang sama menyebabkan peningkatan nilai PV, BD, FV dan SB serta penurunan waktu puncak (peak time, $\mathrm{Pt}$ ) dan suhu awal gelatinisasi (pasting temperature, PT).

Tabel 1. Profil gelatinisasi TKHA pada beberapa jenis perlakuan suhu dan lama pemanasan

\begin{tabular}{|c|c|c|c|c|c|c|c|}
\hline \multirow{2}{*}{ Parameter } & \multirow{2}{*}{ Kontrol } & \multicolumn{3}{|c|}{$54^{\circ} \mathrm{C}$} & \multicolumn{3}{|c|}{$58^{\circ} \mathrm{C}$} \\
\hline & & 4 jam & 5 jam & 6 jam & 4 jam & 5 jam & 6 jam \\
\hline $\mathrm{PV}(\mathrm{cP})$ & $\begin{array}{c}2095,50 \pm \\
133,64^{\mathrm{a}}\end{array}$ & $\begin{array}{c}2451,00 \pm \\
4,24^{\mathrm{C}}\end{array}$ & $\begin{array}{c}2304,00 \pm \\
16,97^{b}\end{array}$ & $\begin{array}{c}5386,50 \pm \\
23,33^{f}\end{array}$ & $\begin{array}{c}4107,00 \pm \\
8,49^{\mathrm{e}}\end{array}$ & $\begin{array}{c}3834,00 \pm \\
4,24^{\mathrm{d}}\end{array}$ & $\begin{array}{c}4177,50 \pm \\
6,36^{\mathrm{e}}\end{array}$ \\
\hline $\mathrm{TV}(\mathrm{cP})$ & $\begin{array}{c}1140,00 \pm \\
72,12^{\mathrm{b}}\end{array}$ & $\begin{array}{c}1161,00 \pm \\
8,49^{\mathrm{b}}\end{array}$ & $\begin{array}{c}979,50 \pm \\
14,85^{\mathrm{a}}\end{array}$ & $\begin{array}{c}2763,00 \pm \\
4,24^{\dagger}\end{array}$ & $\begin{array}{c}1506,00 \pm \\
8,49^{d}\end{array}$ & $1293,00^{c}$ & $\begin{array}{c}2130,00 \pm \\
21,21^{\mathrm{e}}\end{array}$ \\
\hline $\mathrm{BD}(\mathrm{cP})$ & $\begin{array}{c}955,50 \pm \\
61,52^{\mathrm{a}}\end{array}$ & $\begin{array}{c}1290,00 \pm 1 \\
2,73^{\mathrm{b}}\end{array}$ & $\begin{array}{c}1324,50 \pm \\
2,12^{\mathrm{b}}\end{array}$ & $\begin{array}{c}2623,50 \pm \\
19,09^{\mathrm{e}}\end{array}$ & $2601,00^{\mathrm{de}}$ & $\begin{array}{c}2541,00 \pm \\
4,24^{\mathrm{d}}\end{array}$ & $\begin{array}{c}2047,50 \pm 14 \\
85^{\mathrm{c}}\end{array}$ \\
\hline $\mathrm{FV}(\mathrm{cP})$ & $\begin{array}{c}1704,00 \pm \\
106,07^{\mathrm{c}}\end{array}$ & $\begin{array}{c}1591,50 \pm \\
19,09^{b}\end{array}$ & $\begin{array}{c}1375,50 \pm \\
10,61^{\mathrm{a}}\end{array}$ & $\begin{array}{c}4156,50 \pm \\
10,61^{g}\end{array}$ & $2115,00^{e}$ & $\begin{array}{c}1840,50 \pm \\
6,36^{\mathrm{d}}\end{array}$ & $\begin{array}{c}3003,00 \pm \\
42,43^{f}\end{array}$ \\
\hline $\mathrm{SB}(\mathrm{cP})$ & $\begin{array}{c}564,00 \pm \\
33,94^{\mathrm{b}}\end{array}$ & $\begin{array}{c}430,50 \pm \\
10,61^{a}\end{array}$ & $\begin{array}{c}396,00 \pm \\
4,24^{\mathrm{a}}\end{array}$ & $\begin{array}{c}1393,50 \pm \\
14,85^{\mathrm{e}}\end{array}$ & $\begin{array}{c}604,50 \pm \\
2,12^{\mathrm{C}}\end{array}$ & $\begin{array}{c}547,50 \pm \\
6,36^{\mathrm{b}}\end{array}$ & $\begin{array}{c}873,00 \pm \\
21,21^{d}\end{array}$ \\
\hline $\begin{array}{l}\mathrm{Pt} \text { (menit) } \\
\mathrm{PT}\left({ }^{\circ} \mathrm{C}\right)\end{array}$ & $\begin{array}{c}5,47 \pm 0,09^{a} \\
68,45^{\mathrm{a}}\end{array}$ & $\begin{array}{c}5,97 \pm 0,05^{\mathrm{b}} \\
71,60^{\mathrm{c}}\end{array}$ & $\begin{array}{c}5,94 \pm 0,09^{b} \\
71,85 \pm 0,28^{\mathrm{c}}\end{array}$ & $\begin{array}{c}7,20^{\mathrm{d}} \\
77,88 \pm 0,32^{\mathrm{e}}\end{array}$ & $\begin{array}{c}5,60^{\mathrm{a}} \\
69,68 \pm 0,04^{\mathrm{b}}\end{array}$ & $\begin{array}{c}5,50 \pm 0,04^{\mathrm{a}} \\
69,60^{\mathrm{b}}\end{array}$ & $\begin{array}{c}7,04 \pm 0,05^{\mathrm{c}} \\
74,70 \pm 0,28^{\mathrm{d}}\end{array}$ \\
\hline
\end{tabular}

Keterangan: Huruf berbeda pada baris yang sama menunjukkan perbedaan yang signifikan $(P<0,05)$ 
Peningkatan nilai viskositas tersebut mengindikasikan peningkatan kemampuan penyerapan air dan daya kembang, penurunan daya tahan terhadap proses pemanasan yang disertai pengadukan, serta peningkatan kecenderungan retrogradasi TKHA. Nilai Pt dan PT TKHA menurun seiring dengan meningkatnya suhu pemanasan namun nilainya tetap lebih tinggi dari $\mathrm{TKH}$, mengindikasikan peningkatan daya tahan TKHA terhadap panas karena dibutuhkan suhu pemanasan yang lebih tinggi untuk memecah ikatan antar-granula pati TKHA yang telah mengalami penguatan ikatan. Proses annealing menyebabkan terjadinya reorganisasi molekul pati, sehingga dihasilkan konformasi molekul pati yang lebih stabil dan kompak dan daerah kristalin pati yang lebih luas (Zavareze dan Dias, 2011). BeMiller (2018) menyatakan bahwa secara umum annealing dapat meningkatkan suhu awal dan suhu puncak gelatinisasi.

Faktor lama pemanasan memberikan pengaruh yang signifikan $(P<0,05)$ terhadap semua parameter pada profil gelatinisasi, walau hasil uji lanjut menunjukkan tak ada beda nyata pada Pt dan PT TKHA di lama pemanasan 4 dan 5 jam. Peningkatan lama pemanasan menyebabkan penurunan SB dan FV, mengindikasikan penurunan kecenderungan retrogradasi TKHA. Tabel 1 menunjukkan karakteristik $\mathrm{BD}$ yang jauh berbeda antara suhu pemanasan 54 dan $58^{\circ} \mathrm{C}$ seiring dengan meningkatnya lama pemanasan. Penggunaan suhu $54^{\circ} \mathrm{C}$ menyebabkan terjadinya peningkatan $\mathrm{BD}$, sedangkan penggunaan suhu $58^{\circ} \mathrm{C}$ justru menyebabkan terjadinya penurunan BD walau nilainya tetap lebih tinggi dari hasil perlakuan suhu $54^{\circ} \mathrm{C}$.

Karakteristik parameter profil gelatinisasi TKHA yang jauh berbeda dari perlakuan lainnya juga ditunjukkan oleh perlakuan annealing dengan lama pemanasan 6 jam, seperti misalnya pada perlakuan $58^{\circ} \mathrm{C}: 6$ jam. Perbedaan serupa juga dilaporkan terjadi pada proses annealing tepung ketan putih pada penelitian Li et al. (2018) dan proses annealing pati gandum, kentang serta yam pada penelitian Wang et al. (2017). Kedua penelitian tersebut menyatakan bahwa hal tersebut dapat terjadi karena penggunaan suhu yang terlalu tinggi ataupun waktu pemanasan yang terlalu lama pada proses annealing.

Interaksi antara kedua faktor annealing memberikan pengaruh yang signifikan $(P<0,05)$ terhadap semua parameter pada profil gelatinisasi TKHA, mengindikasikan dapat dihasilkannya profil gelatinisasi yang optimum dari kombinasi perlakuan annealing tersebut. Profil gelatinisasi TKHA hasil perlakuan $54^{\circ} \mathrm{C}: 4$ jam dan $54^{\circ} \mathrm{C}: 5$ jam menunjukkan $\mathrm{BD}$ yang rendah, penurunan FV dan SB serta peningkatan PV jika dibandingkan dengan $\mathrm{TKH}$, mengindikasikan karakteristik produk akhir dengan tekstur yang agak kenyal dan tetap lembut walau disimpan dalam jangka waktu lama, serta daya kembang yang tinggi dan laju sineresis yang rendah, sehingga berpotensi sebagai bahan baku dalam pengolahan pangsit beku (Li et al., 2018) dan bahan tepung komposit dalam pengolahan roti (Thiranusornkij et al., 2018) dan kue (Itthivadhanapong dan Sangnark, 2016). Profil gelatinisasi TKHA hasil perlakuan $54^{\circ} \mathrm{C}: 6$ jam, $58^{\circ} \mathrm{C}: 4$ jam, dan $58^{\circ} \mathrm{C}: 6$ jam menunjukkan peningkatan PV, SB dan FV jika dibandingkan dengan $\mathrm{TKH}$, mengindikasikan karakteristik adonan yang cepat mengeras dengan konsistensi adonan yang tinggi serta tekstur akhir yang kenyal dan padat sehingga mudah dicetak (waktu proses menjadi lebih singkat), seperti yang diharapkan dalam pembuatan kirimochi (kue beras ketan khas Jepang) (Kobayashi dan Nishimura, 2007; Kodama et al., 2011). Profil gelatinisasi TKHA hasil perlakuan $58^{\circ} \mathrm{C}: 5$ jam menunjukkan penurunan $\mathrm{SB}$ serta peningkatan PV dan FV jika dibandingkan dengan $\mathrm{TKH}$, mengindikasikan karakteristik adonan yang cepat mengeras dengan tekstur akhir yang sangat kenyal, lengket dan lembut serta laju sineresis yang rendah, seperti yang diharapkan dalam pembuatan dodol ketan (Afriyanti, 2017), wagashi (kue beras ketan khas Jepang) (Kobayashi dan Nishimura, 2007) dan injoelmi (kue beras ketan khas Korea) (Han et al., 2005).

\section{Komponen antioksidan}

Hasil analisis dalam penelitian ini dinyatakan dalam cyanidin-3-glucoside equivalent (C3GE) untuk kadar total antosianin (TA), gallic acid equivalent (GAE) untuk kadar total senyawa fenolik (TSF) dan ascorbic acid equivalent (AAE) untuk kapasitas antioksidan. Hasil analisis BKH menunjukkan kadar TA dan TSF sebesar 194,12 $\pm 0,24 \mathrm{mg}$ C3GE/100 $\mathrm{g}$ dan $304,25 \pm 3,89 \mathrm{mg} \mathrm{GAE} / 100 \mathrm{~g}$. Studi komparasi dengan Nindita et al. (2018) menunjukkan bahwa kadar TA dan TSF pada penelitian ini lebih tinggi dari $\mathrm{BKH}$ varietas Bantul $(70,30 \mathrm{mg}$ C3GE/100 g dan $36,01 \mathrm{mg} \mathrm{GAE} / 100 \mathrm{~g}$ ) maupun Banjarnegara $(179,30 \mathrm{mg}$ C3GE/100 g dan $114,06 \mathrm{mg} \mathrm{GAE} / 100$ g). Perbedaan tersebut dapat disebabkan oleh perbedaan varietas, lokasi tumbuh, umur panen, maupun proses preparasi sampel dari BKH yang digunakan (Zhang et al., 2010).

Hasil analisis komponen antioksidan TKHA pada Tabel 2 menunjukkan bahwa kadar komponen antioksidan TKHA secara keseluruhan menjadi lebih rendah dari TKH. Faktor suhu, faktor lama pemanasan serta interaksi antarkeduanya sama-sama memberikan pengaruh yang signifikan dan berbeda nyata $(P<0,05)$ terhadap kadar TA, TSF, DPPH dan FRAP TKHA. Semakin tinggi suhu dan lama pemanasan, semakin rendah juga kadar komponen tersebut, sejalan dengan pernyataan Suhartatik et al. (2013). 
Tabel 2. Komponen antioksidan TKH termodifikasi annealing

\begin{tabular}{|c|c|c|c|c|}
\hline \multirow{2}{*}{ Perlakuan } & \multirow{2}{*}{$\begin{array}{l}\text { Total Antosianin } \\
(\mathrm{mg} \text { C3GE/100 g) }\end{array}$} & \multirow{2}{*}{$\begin{array}{l}\text { Total Senyawa Fenolik } \\
(\mathrm{mg} \mathrm{GAE} / 100 \mathrm{~g})\end{array}$} & \multicolumn{2}{|c|}{ Kapasitas Antioksidan (mg AAE/100 g) } \\
\hline & & & DPPH & FRAP \\
\hline $54^{\circ} \mathrm{C}: 4 \mathrm{jam}$ & $103,78 \pm 2,24$ & $241,65 \pm 1,98^{\dagger}$ & $267,14 \pm 3,23^{\mathrm{e}}$ & $473,94 \pm 1,43^{\dagger}$ \\
\hline $54^{\circ} \mathrm{C}: 5 \mathrm{jam}$ & $92,09 \pm 0,12^{\mathrm{e}}$ & $229,38 \pm 3,71^{\mathrm{e}}$ & $213,82 \pm 3,23^{d}$ & $413,33 \pm 7,14^{\mathrm{e}}$ \\
\hline $54^{\circ} \mathrm{C}: 6 \mathrm{jam}$ & $49,09 \pm 1,65^{\mathrm{b}}$ & $158,63 \pm 3,36^{b}$ & $150,22 \pm 3,77^{b}$ & $349,19 \pm 2,14^{b}$ \\
\hline $58^{\circ} \mathrm{C}: 4 \mathrm{jam}$ & $78,99 \pm 1,66^{\mathrm{d}}$ & $213,25 \pm 1,77^{\mathrm{d}}$ & $186,02 \pm 5,92^{c}$ & $383,54 \pm 3,57^{d}$ \\
\hline $58^{\circ} \mathrm{C}: 5 \mathrm{jam}$ & $63,04 \pm 1,30^{c}$ & $184,38 \pm 3,01^{c}$ & $159,36 \pm 4,85^{\mathrm{b}}$ & $358,28 \pm 2,14^{\mathrm{c}}$ \\
\hline $58^{\circ} \mathrm{C}: 6 \mathrm{jam}$ & $36,65 \pm 0,83^{a}$ & $146,50 \pm 3,54^{\mathrm{a}}$ & $111,37 \pm 2,69^{a}$ & $311,82 \pm 2,14^{\mathrm{a}}$ \\
\hline
\end{tabular}

$304,25 \pm 3,89 \mathrm{mg} \mathrm{GAE} / 100 \mathrm{~g}$. Huruf berbeda pada kolom yang sama menunjukkan perbedaan yang signifikan $(P<0,05)$

Penurunan kadar TA lebih dari $50 \%$ terjadi pada seluruh perlakuan annealing selain perlakuan $54^{\circ} \mathrm{C}: 4$ jam (tersisa $\pm 53,47 \%$ dari kadar awalnya), sedangkan penurunan kadar TSF lebih dari $50 \%$ hanya terjadi pada perlakuan annealing $58^{\circ} \mathrm{C}: 6$ jam (tersisa $\pm 48,15 \%$ dari kadar awalnya). Hal tersebut menunjukkan bahwa kerusakan akibat panas yang terjadi pada senyawa fenolik lebih rendah dari antosianin, mengindikasikan sifat senyawa fenolik yang lebih stabil terhadap pemanasan. Hal tersebut sejalan dengan pernyataan Bolea et al. (2019) bahwa laju degradasi panas antosianin secara signifikan jauh lebih cepat dari senyawa fenolik, membuktikan bahwa senyawa fenolik lebih tahan terhadap proses pemanasan daripada antosianin.

Kemampuan antosianin dan senyawa fenolik TKHA sebagai komponen antioksidan dapat diindikasikan dari hasil analisis kapasitas antioksidan. Kapasitas antioksidan pada penelitian ini diuji menggunakan dua metode, yaitu berdasarkan metode DPPH dan FRAP. Hasil analisis keragaman menunjukkan bahwa faktor suhu, faktor lama pemanasan maupun interaksi keduanya sama-sama memberikan pengaruh yang signifikan $(P<0,05)$ terhadap kapasitas antioksidan TKHA. Hasil uji lanjut mengindikasikan adanya beda nyata $(P<0,05)$ pada kapasitas antioksidan metode DPPH dan FRAP tiap perlakuan, kecuali pada kapasitas antioksidan metode DPPH perlakuan $54^{\circ} \mathrm{C}: 6$ jam dan $58^{\circ} \mathrm{C}: 5 \mathrm{jam}$.

Hasil analisa metode DPPH dan FRAP menunjukkan kecenderungan yang serupa, yaitu terjadinya penurunan kapasitas antioksidan TKHA seiring dengan peningkatan suhu dan lama pemanasan proses annealing. Peningkatan lama pemanasan dari 4 jam menjadi 6 jam pada suhu 54 dan $58^{\circ} \mathrm{C}$ menyebabkan penurunan kapasitas antioksidan hingga lebih dari $40 \%$, sedangkan peningkatan suhu pemanasan dari 54 menjadi $58^{\circ} \mathrm{C}$ menyebabkan penurunan kapasitas antioksidan sebesar $25-30 \%$. Penurunan tersebut diduga dipengaruhi oleh penurunan kadar TA dan TSF. Hasil analisis korelasi Pearson's menunjukkan adanya korelasi yang sangat kuat antara kapasitas antioksidan DPPH dan FRAP dengan kadar total antosianin $(r=0,97$ dan $r=0,96)$ dan senyawa fenolik $(r=0,95$ dan $r=0,94)$, sejalan dengan hasil penelitian Nindita et al. (2018).
Kapasitas antioksidan TKHA mengindikasikan potensi pemanfaatannya dalam pengolahan pangan fungsional. Walau hasil analisis profil gelatinisasi menunjukkan potensi diversifikasi produk olahan TKHA, hanya TKHA hasil perlakuan $54^{\circ} \mathrm{C}: 4$ jam dan $54^{\circ} \mathrm{C}$ : 5 jam yang berpotensi untuk dimanfaatkan dalam pengolahan pangan fungsional karena hanya kedua perlakuan tersebut yang masih memiliki kadar DPPH dan FRAP lebih dari 50\%, dengan kandungan tertinggi pada perlakuan $54^{\circ} \mathrm{C}: 4$ jam. Hasil analisis profil gelatinisasi merekomendasikan penggunaan TKHA hasil perlakuan tersebut sebagai bahan baku dalam pengolahan pangsit beku serta sebagai bahan tepung komposit dalam pengolahan roti dan kue. Hingga saat ini belum ada penelitian terkait kapasitas antioksidan pada pengolahan pangsit beku, namun pada pengolahan roti dan kue berdasarkan hasil penelitian Yu dan Beta (2015) serta Mau et al. (2017) dapat diindikasikan bahwa TKHA dapat menghasilkan produk roti dan kue yang masih tetap memiliki manfaat fungsional, walaupun masih tetap diperlukan penelitian lanjutan untuk mengetahui pengaruh aplikasi TKHA dalam pembuatan pangan fungsional secara lebih spesifik.

\section{KESIMPULAN}

Modifikasi TKH menjadi TKHA melalui proses annealing menyebabkan terjadinya perubahan pada profil gelatinisasi dan komponen antioksidan $\mathrm{TKH}$. Faktor suhu, faktor lama pemanasan dan interaksi keduanya memberikan pengaruh yang signifikan terhadap semua parameter profil gelatinisasi dan komponen antioksidan TKHA kecuali nilai TV. TKHA menunjukkan adanya peningkatan pada viskositas puncak, viskositas panas (kecuali perlakuan $54^{\circ} \mathrm{C}: 5$ jam), waktu puncak dan suhu awal gelatinisasi jika dibandingkan dengan tepung alaminya. Peningkatan tersebut mengindikasikan peningkatan daya tahan TKHA terhadap proses pemanasan. Secara umum, peningkatan suhu pemanasan menyebabkan peningkatan $\mathrm{BD}, \mathrm{SB}$ dan $\mathrm{FV}$, sementara peningkatan lama pemanasan menyebabkan penurunan nilai ketiga parameter tersebut. Proses annealing menghasilkan profil gelatinisasi yang bervariasi, yang mengindikasikan peningkatan potensi diversifikasi 
produk pangan berbasis $\mathrm{TKH}$. Proses annealing menyebabkan penurunan kemampuan antioksidan TKHA secara keseluruhan. Perlakuan $54^{\circ} \mathrm{C}: 4$ jam menghasilkan TKHA dengan kadar komponen antioksidan tertinggi dari seluruh perlakuan (total anto-

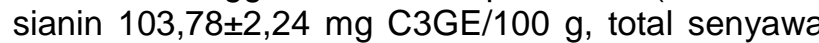
fenolik $241,65 \pm 1,98 \mathrm{mg} \mathrm{GAE} / 100 \mathrm{~g}$, kapasitas antioksidan DPPH $267,14 \pm 3,23 \mathrm{mg}$ AAE/100 $\mathrm{g}$ dan FRAP $473,94 \pm 1,43 \mathrm{mg} \mathrm{AAE} / 100 \mathrm{~g}$ ), sehingga lebih direkomendasikan penggunaannya dalam pengolahan pangan fungsional, terutama sebagai tepung komposit dalam pembuatan roti dan kue.

\section{DAFTAR PUSTAKA}

Abdullah B. 2017. Peningkatan kadar antosianin beras merah dan beras hitam melalui biofortifikasi. J Litbang Pert 36: 91-98. DOI: 10.21082/jp3. v36n2.2017.p91-98.

Afriyanti. 2017. Pemanfaatan residu brem sebagai bahan substitusi pembuatan "Arenia Sticky Rice". J Ilmu Teknosains 3: 22-26.

BeMiller JN. 2018. Physical Modification of Starch. Di dalam: Starch in Food: Structure, Function and Applications: Second Edition. 223-253. Elsevier Inc. Cambridge (GB). DOI: 10.1016/B9 78-0-08-100868-3.00005-6.

Bobo-García G, Davidov-Pardo G, Arroqui C, Vírseda P, Marín-Arroyo MR, Navarro M. 2015. Intralaboratory validation of microplate methods for total phenolic content and antioxidant activity on polyphenolic extracts, and comparison with conventional spectrophotometric methods. J Sci Food Agric 95: 204-209. DOI: 10.1002/jsfa.67 06.

Bolea CA, Grigore-Gurgu L, Aprodu I, Vizireanu C, Stănciuc N. 2019. Process-structure-function in association with the main bioactive of black rice flour sieving fractions. Foods 8: 131. DOI: 10.33 90/foods8040131.

Chen HH, Chang HC, Chen YSYK, Hung CL, Lin SY, Chen YSYK. 2016. An improved process for high nutrition of germinated brown rice production: Low-pressure plasma. Food Chem 191: 120-127. DOI: 10.1016/j.foodchem.2015. 01.083.

Goufo P, Trindade H. 2014. Rice antioxidants: phenolic acids, flavonoids, anthocyanins, proanthocyanidins, tocopherols, tocotrienols, $\mathrm{Y}$-oryzanol, and phytic acid. Food Sci Nutr 2: 75-104. DOI: 10.1002/fsn3.86.

Han JA, Lee BH, Lim WJ, Lim ST. 2005. Utilization of hydroxypropylated waxy rice and corn starches in Korean waxy rice cake to retard retrogradation. Cereal Chem 82: 88-92. DOI: 10.1094/CC-82-0088.

Itthivadhanapong $P$, Sangnark A. 2016. Effects of substitution of black glutinous rice flour for wheat flour on batter and cake properties. Int Food Res J 23: 1190-1198.

Kang MY, Rico CW, Lee SC. 2010. Physicochemical properties of eight popular glutinous rice varieties in Korea. Plant Prod Sci 13: 177-184. DOI: $10.1626 / p p s .13 .177$.

Kobayashi K, Nishimura M. 2007. Waxy rice mutants with unique processing properties for waxy rice breeding. Breeding Sci 57: 175-180. DOI: 10. 1270/jsbbs.57.175.

Kodama I, Shibata C, Fujita N, Ishikawa K, Takahashi $\mathrm{T}$, Nakamura $\mathrm{Y}$, Kawamoto $\mathrm{T}$, Kato K, Sato K, Matsunami M, Akiyama Y. 2011. Starch properties of waxy rice cultivars influencing rice cake hardening. Japan J Food Eng 12: 157-162. DOI: 10.11301/jsfe.12.157.

Li Y, Ding G, Yokoyama W, Zhong F. 2018. Characteristics of annealed glutinous rice flour and its formation of fast-frozen dumplings. J Cereal Sci 79: 106-112. DOI: 10.1016/j.jcs.2017.09.016.

Mau JL, Lee CC, Chen YP, Lin SD. 2017. Physicochemical, antioxidant and sensory characteristics of chiffon cake prepared with black rice as replacement for wheat flour. LWT-Food Sci Technol 75: 434-439. DOI: 10.1016/j.Iwt.2016. 09.019 .

Nindita DA, Kusnandar F, Budijanto S. 2018. Changes in antioxidant and physicochemical properties of Indonesian black rice flour (var. Banjarnegara and Bantul) during no-die extrusion cooking. J Teknol Industri Pangan 29: 164-174. DOI: 10.6066/jtip.2018.29.2.164.

Phetpornpaisan $\mathrm{P}$, Tippayawat $\mathrm{P}$, Jay $\mathrm{M}$, Sutthanut K. 2014. A local Thai cultivar glutinous black rice bran: A source of functional compounds in immunomodulation, cell viability and collagen synthesis, and matrix metalloproteinase-2 and 9 inhibition. J Funct Foods 7: 650-661. DOI: 10.1016/j.jf.2013.12.020.

Ponnappan S, Thangavel A, Sahu O. 2017. Anthocyanin, lutein, polyphenol contents and antioxidant activity of black, red and white pigmented rice varieties. Food Sci Nutr Stud 1: 3. DOI: 10. 22158/fsns.v1n1p43.

Šárka E, Dvořáček V. 2017. New processing and applications of waxy starch - a review. J Food Eng 206: 77-87. DOI: 10.1016/j.jfoodeng.2017. 03.006 . 
Sompong R, Siebenhandl-Ehn S, Linsberger-Martin G, Berghofer E. 2011. Physicochemical and antioxidative properties of red and black rice varieties from Thailand, China and Sri Lanka. Food Chem 124: 132-140. DOI: 10.1016/j.food chem.2010.05.115.

Suhartatik N, Karyantina M, Mustofa A, Cahyanto MN, Raharjo S, Rahayu ES. 2013. Stabilitas ekstrak antosianin beras ketan (Oryza sativa var. glutinosa) hitam selama proses pemanasan dan penyimpanan. Agritech 33: 384-390.

Sutharut J, Sudarat J. 2012. Total anthocyanin content and antioxidant activity of germinated colored rice. Int Food Res J 19: 215-221.

Thiranusornkij L, Thamnarathip $P$, Chandrachai $A$, Kuakpetoon D, Adisakwattana S. 2018. Physicochemical properties of Hom Nil (Oryza sativa) rice flour as gluten free ingredient in bread. Foods 7: 159. DOI: 10.3390/foods71001 59.

Wang Shujun, Wang J, Wang Shaokang, Wang Shuo. 2017. Annealing improves paste viscosity and stability of starch. Food Hydrocolloid 62: 203-211. DOI: 10.1016/j.foodhyd.2016.08.006.
Yu L, Beta T. 2015. Identification and antioxidant properties of phenolic compounds during production of bread from purple wheat grains. Molecules 20: 15525-15549. DOI: 10.3390/mo lecules200915525.

Zahin M, Aqil F, Husain FM, Ahmad I. 2013. Antioxidant capacity and antimutagenic potential of Murraya koenigii. Biomed Res Int 2013: 1-10. DOI: 10.1155/2013/263509.

Zavareze EDR, Dias ARG. 2011. Impact of heatmoisture treatment and annealing in starches- a review. Carbohyd Polym 83: 317-328. DOI: 10.1016/j.carbpol.2010.08.064.

Zhang MW, Zhang RF, Zhang FX, Liu RH. 2010. Phenolic profiles and antioxidant activity of black rice bran of different commercially available varieties. J Agric Food Chem 58: 75807587. DOI: $10.1021 / \mathrm{jf1} 1007665$.

Zulfafamy KE, Ardiansyah, Budijanto S. 2018. Antioxidative properties and cytotoxic activity against colon cancer cell WiDr of Rhizopus oryzae and Rhizopus oligosporus-fermented black rice bran extract. Curr Res Nutr Food Sci 6: 2334. DOI: 10.12944/CRNFSJ.6.1.03. 